Accessions in the Department of Geology include a collection of nearly 200 fossil fruits and seeds from the Cromer forest bed, all described and figured by Mrs. E. M. Reid and her late husband Dr. Clement Reid, and now generously presented by Mrs. Reid. The Trustees approved the purchase for the Department of Minerals of a nugget of well-crystallized iridosmine (osmiridium), weighing nearly an ounce, from Adamsfield near the source of the Derwent in Tasmania. There is a larger nugget already in the collection weighing nearly two ounces and reputed to be the second largest nugget of pure iridosmine, but it is less well crystallized than the specimen now acquired. Other important purchases are a slice weighing 1,387 grammes of a rare type of meteoritea pallasite-from Springwater, Sascatchewan, a fine aurichalcite from Utah, and a fine group of laumontite and a large crystal of adularia from northern Italy.

\section{Televisor, Telegraphy, Telephone}

The word 'Televisor' was coined by Mr. J. L Baird in 1925 to describe apparatus for television and was registered by him as a trade mark. On account, however, of the general adoption of the word in the United States and elsewhere to denote any kind of television apparatus, Baird Television, Ltd., has decided to abandon its registration as a trade mark, so that in future there will be no restriction upon the use of the word in connexion with television. 'Televisor' may thus be used in future as freely as 'telegraph' and 'telephone'. The word telegraph was first applied by Chappe in France, in 1792 , to his invention of the semaphore system of transmitting messages to a distance; and the word telephone was used by Sudré in 1828 for a system of signalling by musical sounds. It was employed in 1844 to describe a powerful wind instrument to convey signals at sea during foggy weather. Philipp Reis, in 1861, called his ingenious instrument a tele. phone, so that he may be regarded as the inventor of the name of the modern instrument. Alexander Graham Bell adopted the word in 1876 for his "Electrical Speaking Telephone".

\section{The Earl's Court Exhibition Centre}

THE new Earl's Court Exhibition building, erected on the site of its predecessor, is approaching completion. It will be the largest permanent exhibition and sports centre in the British Isles. The site covers approximately twenty acres, the new buildings enclosing nine acres. The main arena is unique, as it is the largest concrete building in the country. There are no less than six electric railway tracks running underneath the site of this exhibition. These tracks were covered in by tunnels or bridged without interrupting the railway services. The main hall itself is 250 feet by 350 feet without columns, and has seating accommodation for about 25,000 people. A swimming pool having a capacity of $2 \frac{1}{4}$ million gallons of water is provided. An account is given in the Electrical Times of July 1 of the problems connected with the heating and lighting of the exhibition. Complete designs and estimates were got out for all reasonable methods of doing this. The first step taken was to prepare designs and costs for a complete generating power station for the Exhibition and alternatively to use boiler-house plant for heating purposes. This was compared with possible tariffs obtained from the Fulham Power Station for an electric service for lighting power and complete heating of the building by electric thermal storage. The estimates were considered by the Company and its consultants, the conclusion being that electricity for all purposes was the best scheme. The Fulham Borough Council has undertaken to carry out the complete installation of all the electrical plant and services required up to the point of low. tension distribution together with the electric thermal storage plant, and the work is now on the point of completion. A permanent form of fire-fighting equipment is installed at every substation. The heating of the whole of the building is carried out by an electric thermal storage hot water plant which is much the largest plant of this kind in the British Isles.

\section{History of Alchemy}

There are welcome signs of an awakening interest in the history of science, the study of which has until recently received surprisingly little recognition among the increasing body of scientific workers in Great Britain. The appearance last year of Annals of Science, a quarterly journal devoted to the history of post-Renaissance science in general, has been quickly followed by another publication entitled Ambix, which is to deal with the specialized study of alchemy and early chemistry. Ambix is, indeed, the official journal of the newly founded Society for the Study of Alchemy and Early Chemistry. The first issue is dated May 1937; the second number will appear in November 1937; and thereafter it will be published as a quarterly. At first sight, the subject may appear too restricted to afford material for a quarterly periodical, but this impression is corrected by supplementary glances at Sir Robert Mond's introduction and the later contents of this issue. "Alchemy," writes Sir Robert, "records not only Man's groping for the truth and for the enrich. ment of his experiences, but at the same time the widening of the Human Mind and the accompanying evolution of thought."

ANother point of view is presented by Prof. J. Ruska in his contribution on "Methods of Research in the History of Chemistry". Here he states that "we continually need new texts, we need summaries of contents, translations and commentaries . . . we need also the application of the keenest critical methods." Ambix has already begun to supply material of this kind. Thus, Prof. J. R. Partington contributes a fully documented article entitled "Albertus Magnus on Alchemy"; Dr. F. Sherwood Taylor, the editor, writes upon "The Origins of Greek Alchemy"; Mr. Gerard Heym opens a useful "Introduction to the Bibliography of Alchemy", and also discusses the "Aurea Catena Homeri". There are, 
in addition, a report of a discussion upon chemical and alchemical symbolism; a translation of "The Visions of Zosimos", by Dr. Taylor ; and reviews of four recent books, including notably Prof. Partington's "Origins and Development of Applied Chemistry" and Prof. J. Read's "Prelude to Chemistry". The nature of these two works, differing so widely in scope and treatment, conveys some idea of the ambit of Ambix.

\section{Public Health in British India during 1934}

The annual report of the Public Health Com. missioner with the Government of India (vol. 1), recently issued, surveys the vital statistics, public health and public health services of British India for the year 1934 (Government of India Press, New Delhi, 1936. Rs. 6 As. 2, or 10s.). The mid-year population is estimated to be, $275,753,570$, the births were $9,288,897$, a rate per 1,000 of 34 , and the deaths numbered $6,856,244$, a rate per 1,000 of 25 . The infant mortality per 1,000 live births was 187. Of the causes of death, malaria heads the list with $1,319,026$ deaths, and this figure does not include the mortality caused indirectly by malaria. Deaths from respiratory diseases numbered 483,018, those from dysentery and diarrhœa 285,110 and from cholera 199,708. Smallpox, with 83,928 deaths, caused a greater mortality than plague, with 80,131 deaths. At the Research Institute, Kasauli, a number of cases of snake-bite have been treated with antivenomous serum with a high percentage of recoveries -25 out of 29 cases of cobra bite, and 12 out of 13 cases of bite by Russell's viper. Lieut.-Colonel Jolly, the Commissioner, believes that the intensive public health propaganda carried out during the last ten or twelve years is beginning to bear fruit, and that interest is increasing in such matters as rural reconstruction, nutrition, child welfare and the prevention of epidemics.

\section{Examinations in the United States}

Examination, as a teacher's tool, has undergone remarkable modification in the past sixteen years in the United States. The search for an instrument of precision for the use of teachers in examining their pupils has engaged the ingenuity of a host of investigators, and the resultant devices, the true-false, the completion, the matching, the multiple-choice, the one-word, the problem and other objective-type tests have, to a large extent, supplanted the essay test. The United States Office of Education has recently issued a report (Bulletin 9/1936, Washington : Supt. of Documents. 10 cents) on testing practices of secondary school teachers of 1,600 schools, as described by themselves. It appears that, when constructing tests, about seventy-four per cent of them make use principally of the objective type, only sixteen per cent rely chiefly on the essay test and ten per cent make equal use of both. The report shows that the new style of tests is popular with teachers. Their simplicity appeals to them. But it is clear that their employment calls for watchful control. A principal advantage claimed for them-that a large number of items can be answered in a short time and the subject-matter can thus be the more thoroughly sampled-has been unrealized in many cases through not using a sufficient number of questions. Of intelligence tests, the report says that few teachers really use the results.

\section{The Swiss Earthquake Service}

THE Swiss Seismological Commission, afterwards the Swiss Earthquake Service, is the oldest committee engaged in the study of earthquakes. For its foundation in 1878, we are indebted to the veteran geologist, Prof. Albert Heim. Two years later, it was followed by the British Association Committee on earthquakes in Japan, which, on Prof. Milne's return to Great Britain in 1895, enlarged its scope as the Seismological Committee. In 1883, shortly after the destructive Ischian earthquake of July 28, a geodynamic section was added to the Central Meteorological Office at Rome, which still carries on its useful work of studying Italian and other earthquakes; and, in 1892, the Imperial Earthquake Investigation Committee began its similar, but more extensive, work in Japan. The Swiss Committee, under the direction of Dr. E. Wanner, has recently issued its Jahresbericht for 1935, containing three valuable tables, the first on earthquakes sensible in Switzerland, twenty-seven in number, none of which reached destructive intensity ; the second, of eighty earthquakes with origins as a rule less than three hundred miles distant; and the third, of a hundred and fifty earthquakes recorded at the five Swiss stations (Zurich, Chur, Neuchâtel, Basel and Sion), the distances of the origins being not less than six hundred miles.

\section{Discussion on Lubrication and Lubricants}

THE Council of the Institution of Mechanical Engineers, with the co-operation of other societies and institutions, has decided to hold a general dis. cussion on lubrication and lubricants on October 13 15, when a series of some 140 papers from leading authorities throughout the world will be presented. The opportunity will be taken to review the present state of knowledge by means of a general discussion among those especially interested and qualified to discuss the major problems of the subject, with objects such as to endeavour to establish a correlation between theory and practice and to show how bearing design can be applied, to relate academic research with trade practice, to obtain current views upon bearing metals, and to review the significance of laboratory tests, including wear and friction tests. An exhibition will be held at the Science Museum, South Kensington, to illustrate the subjects under discussion, and will be devoted to lubricants, bearings and bearing materials, as well as to testing and other apparatus. The exhibition will be open for a fortnight from October 13. Support for the discussion has been given by twenty-nine British societies and technical institutions and by ten over-seas societies and technical bodies. The complete proceedings will be issued as a bound volume. Advance copies of the papers will be available for use at the meetings. 